\title{
Characterization of cheese consumers in Santiago Province, Chile
}

\author{
Einar Vargas-Bello-Pérez ${ }^{1}$, Claudio Aguilar¹, Paula Toro-Mujicaㄹ, Raúl R. \\ Vera $^{1}$, Matías Cerda ${ }^{1}$, and Ignacio Briones ${ }^{2}$ \\ ${ }^{1}$ Departamento de Ciencias Animales, Facultad de Agronomía e Ingeniería Forestal, Pontificia Universidad \\ Católica de Chile. Casilla-306-22, Santiago, Chile. \\ ${ }^{2}$ Fondo para la Innovación Agraria, Ministerio de Agricultura. Loreley 1582, La Reina, Santiago, Chile.
}

\begin{abstract}
E. Vargas-Bello-Pérez, C. Aguilar, P. Toro-Mujica, R.R. Vera, M. Cerda, and I. Briones. 2014. Characterization of cheese consumers in Santiago Province, Chile. Cien. Inv. Agr. 41(3):327-335. A high demand for Chilean cheese has resulted in increased cheese production. This increase represents an opportunity to promote the development of new markets, such as for small ruminant cheeses. However, little has been discussed regarding the extent to which cheese consumers consider small ruminant cheeses. We hypothesized that price is the main determining factor for purchasing cheese. The present study examined this previously unexplored aspect. The objective of this study was to identify the factors that contribute to the purchaser's response behavior, including purchase, usage and product possession. This study also aimed to provide preliminary information on cheese consumption in the Province of Santiago, Chile. A personal interview was conducted in a sample of 323 individuals in major supermarkets from five municipalities (Santiago, La Florida, Las Condes, Pudahuel, and Recoleta) of Santiago city between March and May 2012. The largest proportion of surveyed individuals were female (62\%) who were between 20 to 25 years $(34 \%)$. The main cheese purchaser of the household was more often the woman $(52 \% ; \mathrm{P}<0.01)$. The brand and origin $(70 \% ; \mathrm{P} \leq 0.01)$ and price $(30 \% ; \mathrm{P} \leq 0.01)$ of the cheese were the main aspects considered before making a purchase. Cow's milk cheese was the predominant cheese type consumed (77\%), followed by goat's milk cheese (6\%), cow's and goat's milk cheese (15\%) and cow's, goat's and sheep's milk cheese (2\%). Of the individuals surveyed, $35 \%$ consumed cheese three times per week as a sandwich ingredient. We conclude that consumer fidelity is driven by brand and origin and a preference to use the cheese in sandwiches $(81 \%)$. Data from this study may be used to determine the most adequate strategy for promoting the sales of small ruminant cheeses.
\end{abstract}

Key words: Cheese, consumption, small ruminant.

\section{Introduction}

Chile produces three major types of cow's milk cheese: "Mantecoso" or "Chanco"; "Fresco" or

Received May 29, 2014. Accepted October 19, 2014. Corresponding author: evargasb@uc.cl
"Quesillo"; and "Gouda". According to the Office of Agrarian Studies and Policies (ODEPA, 2012), the amount of cheese produced in 2011 was 66,679 $\mathrm{t}$, which is a $3.3 \%$ increase from that produced in 2010. The significant growth in cheese production is due to an increase in per capita income, which generates an augmented demand that also 
includes a 50\% increase in imported cheese in 2011 (approximately 14,000 t) relative to that in 2010 (ODEPA, 2012). Four regions produce the majority of Chilean cheese: La Araucanía (5,499 t), Los Lagos (18, 980 t), Metropolitana de Santiago (357 t), and Los Ríos (41, 713 t) (ODEPA, 2012).

For centuries, goat and sheep farming has been an important part of Mediterranean agriculture. Consequently, Mediterranean countries have established a long-standing and diversified tradition of producing fresh, fermented, or ripened goat's and sheep's milk cheeses (Dubeuf et al., 2010). Goat and sheep milk production is an important and significant sector in southern European countries. This production is concentrated in certain regions associated with high-quality cheeses. Such regions have evolved rapidly into niche markets (Rancourt and Carrere, 2011). The milk of small ruminants, such as goats and sheep, is of particular economic interest in certain areas of the world. In developing countries, the production of this type of milk has become a useful strategy in overcoming malnutrition, especially in infants (Haenlein, 2004). An additional element of interest in the production of the milk of small ruminants is that it is a sustainable resource with excellent possibilities of economic profitability and demographic stability, which is of special importance to arid, semi-arid and other problematic regions of the world (Vera et al., 2009). The consumption of goat's and sheep's milk cheese varies according to the preferences (e.g., as the main ingredient of traditional foods, as the main source of specific nutritional requirements, or because it is the most available cheese) of particular sectors of the population (Sampelayo et al., 2007). Chilean cheese consumers are known to prefer fresh and soft cheeses; for example, sheep's and goat's milk cheeses are generally regarded as gourmet products and are more expensive than cow's milk cheeses (Álvarez-Builla, 2007). Although the demand for goat's and sheep's milk cheeses is not widespread in Chile, there is an incipient internal market for these cheeses, and their production is expected to increase (Navarro and Borquez, 2008).
We designed an exploratory study to identify and characterize the response behavior of cheese purchasers, including purchase, usage and product possession. Such data may be used to develop strategies to promote the sale of small ruminant cheeses. We hypothesized that price is the main limiting factor of cheese purchases. Because our research focuses on the development of animal nutritional strategies to enhance the nutritional value of small ruminant cheeses (Vargas-Bello-Perez et al., 2013a,b; Vera et al., 2009), data from this study may help to determine appropriate strategies for introducing such products to the Chilean market.

\section{Materials and methods}

\section{Participants and locations}

A personal interview was conducted in a sample of 323 individuals from the Province of Santiago, Region Metropolitana, Chile. The survey was conducted in major supermarkets from five municipalities (north, south, east, west and central) of Santiago (Santiago, La Florida, Las Condes, Pudahuel, and Recoleta) between March and May, 2012. The sample size was calculated using stratified sampling with a dichotomous variable, based on the formula of Scheaffer et al. (1987).

The question "Have you eaten cheese in the last month?" was considered to be a dichotomous variable. If the answer was "yes", the participant was asked to complete the entire survey; if the answer was "no", the participant was asked to answer the question "Why did you not eat cheese in the last month?". A confidence interval of $95 \%$ and an estimation error of $5 \%$ with a $p$ value of 0.7 and a q value of 0.3 were calculated using the cheese consumption data reported by the Center of Consumer Opinion of Chile (CEOC, 2006). 


\section{Questionnaires}

A questionnaire was used as the instrument for collecting information, and it was divided into two sections: 1) consumption and 2) purchase. The consumption section comprised questions regarding the frequency of cheese consumption (daily, three times per week, and every week or less), the type of cheese (cow's, sheep's, or goat's milk), the place of consumption (home or elsewhere), and consumption choice (in a sandwich or other foods). The purchase section comprised questions regarding the primary cheese purchaser of the household (the male, the female, or both individuals), any pertinent information considered by the purchaser prior to making the purchase (price and brand/origin), and the purchaser's interest in the label information (nutritional information, fat content, expiry date, or other). Statistical frequency was analyzed using the Chisquare test using the SAS 9.2 statistical package. Statistical significance was set at $\mathrm{P} \leq 0.05$.

\section{Results and discussion}

We designed this study with the intention of characterizing aspects related to the purchase and consumption of cheese, in particular of small ruminant milk cheeses. The characteristics of the sample of consumers surveyed is shown in Table 1. We found that the surveyed individuals were more often female $(62 \%)$ and aged between 20 to 25 years $(34 \%)$. A higher proportion of women than men were surveyed, which reflects that, in Chile, women are more likely to conduct market shopping than men, which was also observed in surveys of meat (Verbeke and Vackier, 2004) and cheese (Mesias et al., 2003) purchases in developed countries.

\section{Consumption behavior}

More surveyed individuals answered "yes" than "no" to the question "Have you eaten cheese in
Table 1. Characteristics of cheese purchasers surveyed ( $n$ $=323$ ) in supermarkets in the Province of Santiago, Chile.

\begin{tabular}{lc}
\hline Characteristic & \% of individuals \\
\hline Gender & 61.6 \\
Women & 38.4 \\
Men & \\
Age & 64.4 \\
20-40 years & 29.4 \\
$41-65$ years & 6.2 \\
>65 years & \\
Frequency of cheese & \\
consumption & 19.4 \\
Daily & 34.8 \\
Three times per week & 45.9 \\
Once per week or less & \\
Type of cheese & 76.7 \\
Cow's milk cheese & 6.1 \\
Goat's milk cheese & 17.6 \\
Cow's, goat's and sheep's & \\
milk cheese & \\
Place of consumption & \\
Home & \\
Elsewhere & \\
Consumption choice & \\
In a sandwich & \\
Other ${ }^{2}$ & \\
\hline
\end{tabular}

${ }^{1}$ Restaurant, a friend's home and at a social event; ${ }^{2}$ In pasta, in pizza and as a snack.

the last month?", and cow's milk cheese was the predominant type of cheese consumed (77\%). Notably, $6 \%$ of the surveyed individuals consumed goat's milk cheese, $15 \%$ consumed cow's and goat's milk cheeses and a small proportion $(2 \%)$ consumed cheese made with cow's, goat's and sheep's milk. Of the individuals surveyed, $35 \%$ consumed cheese three times per week, $97 \%$ consumed cheese at home, $81 \%$ consumed cheese as an ingredient in sandwiches, and $27 \%$ did not consume cheese in the last month because of a lack of habit. The cheese consumption frequency in our study is similar to that reported in previous studies (Young et al., 2004; Mónika-Anetta, 2012). 
Table 2. Purchasing behavior of cheese purchasers surveyed $(n=323)$ in supermarkets in the Province of Santiago, Chile.

\begin{tabular}{lc}
\hline Behavior & $\%$ of individuals \\
\hline Main cheese purchaser of the household & \\
The woman & 51.6 \\
The man & 22.2 \\
Both the woman and the man & 22.2 \\
Other ${ }^{1}$ & 4.0 \\
Consumer interest before the purchase & \\
Price & 30.5 \\
Brand/origin & 69.5 \\
Consumer interest in labeling & \\
$\quad$ Nutritional information & 25.5 \\
Fat content & 15.4 \\
Expiration date & 51.8 \\
No interest & 7.2 \\
\hline
\end{tabular}

${ }^{1} \mathrm{~A}$ child or housekeeper.

\section{Purchase}

The purchasing behavior of cheese consumers are presented in Table 2 and the behavioral characteristics, according to gender and age, are presented in Table 3. The main cheese purchaser of the household was most often the woman. Brand and origin $(70 \%)$, followed by price, were the main aspects considered before purchasing cheese (Table 4). These findings differ from those reported by Young et al. (2004), in which Cheddar cheese consumers stated that price and flavor were the main traits influencing their purchase decision.

The data on purchasing decisions are presented in Table 4 . We observed that the expiration date was the main label information read by the purchaser, indicating that in addition to consumer fidelity based on the cheese brand, the cheese purchaser is aware of the importance of the expiration date and verifies it before making the purchase.

In this study, brand and origin were the most important factor in the decision-making process when purchasing cheese, which is in partial agreement with studies on beef consumption in Chile
(Schnettler et al., 2004, 2008, 2009) that reported overall results from a conjoint analysis and showed that the origin of the product dominated consumer preferences in the selection of beef. In addition, our results are in support of the study by Mesias et al. (2003), who reported that brand and origin designation were the main aspects considered by cheese consumers in Extremadura, Spain.

The analysis of the effect of age in addition to that of gender in relation to label information (Table 5 ) indicates a strong dependence between both sets of variables, and suggests that both gender and age group influenced the relative importance given to the label contents. The disaggregations of the data ( $\mathrm{P} \leq 0.007$; data not shown) indicated that middle-age females placed more importance on nutritional information than males of the same age, while the latter group focused largely on the date of expiration. This is an expected finding as females aged 26-40 years are likely to be raising children and may be more concerned with nutritional information than males of the same age.

The strategy used by consumers to make decisions regarding purchasing brands is of interest to marketers. Marketers need to determine the amount of information to provide in their brand communications and the level of involvement needed for making purchasing decisions (Cronin et al., 2000). Houston and Rothschild (1978) believed that this involvement may occur in different forms. They viewed involvement not as a property of the individual but as a relationship between individual characteristics, such as personal goals and the experience of the consequences of buying and consuming, and the stimuli presented by the communication, product or situation. Therefore, the dynamic and persistent nature of the relationship is reflected in the distinction between "enduring involvement" and "situational involvement". Mittal and Lee (1989) also focused on brand-related decisions and described two additional forms of involvement, namely product involvement and brand decision involvement (purchase involvement). 
Table 3. Behavioral characteristics, grouped by gender and age, of cheese purchasers surveyed $(n=323)$ in supermarkets in the Province of Santiago, Chile.

\begin{tabular}{|c|c|c|c|c|}
\hline Behavioral characteristic & Male & Female & P-value & \\
\hline \multicolumn{5}{|l|}{ Have you eaten cheese in the last month? } \\
\hline Yes & 109 & 170 & \multirow{2}{*}{0.53} & \\
\hline No & 15 & 29 & & \\
\hline \multicolumn{5}{|l|}{ Why did not you eat cheese in the last month? } \\
\hline Dislike & 11 & 20 & \multirow[t]{2}{*}{0.69} & \\
\hline Other $^{1}$ & 4 & 9 & & \\
\hline \multicolumn{5}{|l|}{ Type of cheese } \\
\hline Cow's milk cheese & 88 & 138 & \multirow{2}{*}{0.20} & \\
\hline Cow's, goat's and sheep's milk cheese & 23 & 44 & & \\
\hline \multicolumn{5}{|l|}{ Frequency of cheese consumption } \\
\hline Daily & 21 & 33 & \multirow{3}{*}{0.47} & \\
\hline Three times per week & 38 & 59 & & \\
\hline Once per week or less & 50 & 78 & & \\
\hline \multicolumn{5}{|l|}{ Place of consumption } \\
\hline At home & 105 & 165 & \multirow{2}{*}{0.30} & \\
\hline Elsewhere $^{2}$ & 4 & 5 & & \\
\hline \multicolumn{5}{|l|}{ Consumption choice } \\
\hline In a sandwich & 88 & 138 & \multirow{3}{*}{0.88} & \\
\hline In pasta & 10 & 16 & & \\
\hline \multirow[t]{2}{*}{ As an ingredient in pizza or as a snack } & 11 & 16 & & \\
\hline & \multicolumn{3}{|c|}{ Age group (years) } & \\
\hline Have you eaten cheese in the last month? & $20-25$ & $26-55$ & $\geq 56$ & P-value \\
\hline Yes & 95 & 136 & 48 & \multirow{2}{*}{0.51} \\
\hline No & 15 & 22 & 7 & \\
\hline Why did not you eat cheese in the last month? & $20-40$ & $\geq 41$ & & \\
\hline Dislike & 19 & 12 & & \multirow{2}{*}{0.51} \\
\hline Other $^{1}$ & 8 & 5 & & \\
\hline \multicolumn{5}{|l|}{ Type of cheese } \\
\hline Cow's milk cheese & 71 & 107 & 35 & \multirow{2}{*}{0.16} \\
\hline Goat's, cow's and sheep's milk cheese & 22 & 33 & 11 & \\
\hline \multicolumn{5}{|l|}{ Frequency of cheese consumption } \\
\hline Daily & 18 & 27 & 9 & \\
\hline Three times per week & 32 & 49 & 16 & \multirow{2}{*}{0.90} \\
\hline Once per week, once every fifteen days, or once a month & 43 & 64 & 21 & \\
\hline Place of consumption & $20-40$ & $\geq 41$ & & \multirow{3}{*}{0.55} \\
\hline At home & 175 & 95 & & \\
\hline Elsewhere $^{2}$ & 6 & 3 & & \\
\hline \multicolumn{5}{|l|}{ Consumption choice } \\
\hline In a sandwich & 75 & 113 & 37 & \multirow{2}{*}{0.08} \\
\hline Other $^{3}$ & 18 & 27 & 9 & \\
\hline
\end{tabular}

'On medical advice, "makes me ill" and "is fatty"; ${ }^{2}$ Restaurant, a friend's place, and at a social event; ${ }^{3}$ In pasta, in pizza and as a snack. Expected frequencies with a magnitude of less than 5 are combined with adjacent elements resulting in a reduction of cells used to formulate the Chisquared test. Statistical significance was determined using Chi-square analysis. 
Table 4. Purchasing behavior, grouped by gender and age, of cheese purchasers surveyed $(n=323)$ in supermarkets in the Province of Santiago, Chile.

\begin{tabular}{|c|c|c|c|c|}
\hline Behavior & Male & Female & P-value & \\
\hline \multicolumn{5}{|l|}{ Main cheese purchaser of the household } \\
\hline The woman & 56 & 88 & \multirow{4}{*}{$<0.01$} & \\
\hline The man & 24 & 38 & & \\
\hline Both the woman and the man & 24 & 38 & & \\
\hline A child or housekeeper & 4 & 7 & & \\
\hline \multicolumn{5}{|c|}{ Information considered by the customer before purchasing the cheese } \\
\hline Price & 33 & 52 & \multirow{2}{*}{0.01} & \\
\hline Brand/origin & 76 & 118 & & \\
\hline \multicolumn{5}{|l|}{ Label information read by the customer } \\
\hline Nutritional information & 28 & 43 & \multirow{4}{*}{0.50} & \\
\hline Fat content & 17 & 26 & & \\
\hline Expiry date & 57 & 88 & & \\
\hline \multirow[t]{2}{*}{ No interest } & 8 & 12 & & \\
\hline & \multicolumn{3}{|c|}{ Age (years) } & \\
\hline Person who buys cheese & $20-25$ & $26-55$ & $\geq 56$ & P-value \\
\hline Woman & 21 & 31 & 10 & \multirow{3}{*}{0.11} \\
\hline Man & 48 & 72 & 24 & \\
\hline The woman, the man, a child, or housekeeper & 24 & 37 & 12 & \\
\hline \multicolumn{5}{|c|}{ Information considered by the customer before purchasing the cheese } \\
\hline Price & 28 & 43 & 14 & \multirow{2}{*}{0.57} \\
\hline Brand/origin & 65 & 97 & 32 & \\
\hline \multicolumn{5}{|l|}{ Label information read by the customer } \\
\hline Nutritional information & 46 & 13 & 12 & \multirow{4}{*}{0.14} \\
\hline Fat content & 28 & 8 & 7 & \\
\hline Expiry date & 94 & 27 & 24 & \\
\hline No interest & 13 & 4 & 3 & \\
\hline
\end{tabular}

*Expected frequencies with a magnitude of less than 5 are combined with adjacent elements resulting in a reduction of cells used to formulate the Chi-squared test. Significant differences were determined using Chi-square analysis.

Table 5. Proportions (\%) of customer interest according to gender and age (years) in cheese purchasers surveyed in supermarkets in the Province of Santiago, Chile.

\begin{tabular}{lllllllll}
\hline & \multicolumn{3}{c}{ Male } & & \multicolumn{3}{c}{ Female } \\
\cline { 2 - 4 } \cline { 7 - 9 } Preference & $(15-25)$ & $(26-40)$ & $(>41)$ & & $(15-25)$ & $(26-40)$ & $(>41)$ \\
\hline Nutritional information & 34.0 & 13.6 & 31.3 & & 33.0 & 19.5 & 24.5 \\
Fat content & 35.8 & 42.4 & 15.6 & & 37.5 & 40.2 & 18.9 \\
Expiration date & 30.2 & 44.1 & 53.1 & & 29.5 & 40.2 & 56.6 \\
\hline
\end{tabular}

Probability of Chi-square $=0.003$; all chi-square tests were carried out on actual counts, although the corresponding proportions are presented as percentages for interpretation simplicity. 
Furthermore, a highly involved consumer actively compares brands and uses more purchase locations and is consequently more informed and can provide the marketer with the first indication of customer dissatisfaction with product offerings. Consumer involvement can be used to segment markets. This study provides data on shopping frequency, which marketers may consider when targeting specific segments. If a marketer can generate more enduring involvement through a clear understanding of the salient elements that stimulate interest in a product category, then consumer commitment to that product category may follow, resulting in a lower risk in new product acceptance.

This study was associated with certain limitations. By not focusing on a particular type of cheese, we are unable to relate our findings to the small ruminant's milk cheese market. Therefore, it would be of use to confirm our results by extending the scope of the research to other geographical areas of Chile and focusing on at least one type of small ruminant cheese or considering the brand and origin of different cheeses. We also acknowledge the inherent limitations of using convenience samples. Future research should consider the brand and origin of different cheeses and assess consumer fidelity, which was not included in the main objectives and consequent study design of our preliminary study.

Overall, in the province of Santiago, female consumers aged between 26 and 55 years are the main cheese purchasers, and their purchase decision depends on the brand and origin of the cheese. Data from this study may help to identify niche markets, such as purchasers that prefer small ruminant milk cheeses.

\section{Acknowledgements}

This study was supported by a research grant from Fondo de Innovación Agraria, Ministerio de Agricultura, Chile (FIA PYT-2008-0213).

\section{Resumen}

E. Vargas-Bello-Pérez, C. Aguilar, P. Toro-Mujica, R. R. Vera, M. Cerda e I. Briones. Caracterización de consumidores de queso en la Provincia de Santiago, Chile. Cien. Inv. Agr. 41(3):327-335. La producción de queso en Chile está creciendo debido a un alza en su demanda; este fenómeno podría representar una oportunidad para promover el desarrollo de nuevos mercados (quesos de rumiantes menores), sin embargo, poco se ha investigado sobre el consumo de quesos. La hipótesis que se contrasta es que los sujetos que compran queso en el mercado lo hacen con un grado débil de implicación, donde el precio del producto es la variable más importante en el comportamiento de compra. Este estudio tiene por objetivo identificar funciones de respuesta comportamental, para analizar los procesos de adquisición, utilización, y posesión del producto en la Provincia de Santiago en Chile. Un cuestionario personal fue realizado a una muestra de 323 personas en supermercados de cinco comunas (Santiago, La Florida, Las Condes, Pudahuel y Recoleta) de la ciudad de Santiago entre marzo y mayo del 2012. La mayor proporción de personas encuestadas resultó ser mujeres $(62 \%)$ entre 20 y 25 años de edad (34\%). Las mujeres $(52 \% ; \mathrm{P} \leq 0.01)$ resultaron ser las personas que se encargan de comprar el queso mientras que marca y origen $(70 \% ; \mathrm{P} \leq 0.01)$ y precio $(30 \% ; \mathrm{P} \leq 0.01)$ fueron los aspectos más importantes que el consumidor considera antes de realizar la compra de queso. El queso de origen vacuno fue el queso que más se consume (77\%), la diferencia se distribuye en queso de cabra (6\%), queso de vaca y queso de cabra (15\%) y quienes consumieron queso de vaca, cabra y oveja (2\%). Del total de encuestados, el $35 \%$ consume queso tres veces a la semana como un ingrediente en sandwiches. Se puede concluir que la acción de compra 
de queso tiene una débil implicación, como generalmente se asume, con una aprehensión complementaria entre racional y emocional. Ello se explica por una presumible alta tasa de fidelidad a marca/origen en quesos cuya principal característica es ser suave, característica que lo hace apropiado para el fin que se utiliza (81\%): sandwich. Los resultados de este estudio podrían ser utilizados para encontrar la forma más apropiada de ingresar al mercado de quesos de pequeños rumiantes: un uso práctico y habitual.

Palabras clave: Consumo, queso, rumiantes menores.

\section{References}

Álvarez-Builla, M. 2007. El mercado de productos delicatessen en Chile. Instituto Español de Comercio Exterior. Available online at: http://www.oficinascomerciales.es/ icex/cda/controller/pageOfecomes/0,5310, 5280449_5282923_5287111_4435025_-1,00. html (Website accessed: December 10, 2012).

CEOC. 2006. Hábitos alimenticios de los chilenos. Centro de estudios de opinión ciudadana. Julio 2006. Available online at: http://www.ceoc.cl/ pdf/Estudios_Opinion/2006/ Informe_Habitos_ Alimenticios_de_los_Chilenos_Julio_2006.pdf (Website accessed: December 10, 2012).

Cronin, J. J., M.K., Brady, and G.T.M. Hult. 2000. Assessing the effects of quality, value, and customer satisfaction on consumer behavioral intentions in service environments. Journal of Retailing 76:193-218.

Dubeuf, J.P., F.D.R., Morales, and J.M.C. Genis, 2010. Initiatives and projects to promote the Mediterranean local cheeses and their relations to the development of livestock systems and activities. Small Ruminant Research 93:67-75.

Haenlein, G.F.W. 2004. Goat milk in human nutrition. Small Ruminant Research 51:155-163.

Houston, M.J. and M.L. Rothschild. 1978. Conceptual and methodological perspectives on involvement. American Marketing Association 184-187.

Mittal, B., and M. S. Lee. 1989. A causal model of consumer involvement. Journal of Economic Psychology 10:363-389.

Mónika-Anetta, A., 2012. Romanian Cheese Market Segmentation. Economy, Business and Management 5: 31-42.
Mesias, F., Escribano, M., Rodríguez, A. and Pulido, F., 2003. Market segmentation of cheese consumers: an approach using consumer's attitudes, purchase behavior and socio demographic variables. International Journal of Dairy Technology 56:149-155.

Navarro, R., and F. Bórquez. 2008. Resultados y Lecciones en Producción de Leche y Queso de Oveja Latxa Proyectos de Innovación en Región de Los Ríos y Región de Los Lagos. Fundación para la innovación agraria. Ministerio de Agricultura, Chile. Available online at: http://experiencias.innovacionagraria.cl (Website accessed: December 10, 2012).

ODEPA. 2012. Estadísticas /por macro rubros/ lácteas. Oficina de Estudios y Políticas Agrarias (ODEPA). Available online at http://www.odepa. gob.cl/jsp/lacteos/seil/seil_i5trp_enc.jsp. (Website accessed: December 10, 2012).

Rancourt, de M. and L. Carrère. 2011. Milk sheep production systems in Europe: Diversity and main trends. In: A. Bernués, J.P. Boutonnet, Casasus, M. Chentouf, D. Gabiña, M. Joy, A. López-Francos, P. Morand-Fehr, F. Pacheco (eds.). Economic, social and environmental sustainability in sheep and goat production systems. Zaragoza, Spain. Options Méditerranéennes, Série A (Séminaires Méditerranéens), No. 100.

Sampelayo, M.R.S., Y. Chilliard, P. Schmidely, and J. Boza. 2007. Influence of type of diet on the fat constituents of goat and sheep milk. Small Ruminant Research 68:42-63.

Scheaffer, R. L., W. Mendenhall, and L. Ott. 1987. Elementos de muestreo. Rendón, S. G. and Gómez, A.J.R. (Trad.) Grupo Editorial Iberoamérica, México, D. F. 321 pp. 
Schnettler, B., O. Manquilef, and H. Miranda. 2004. Atributos valorados en la selección de carne bovina en supermercados de Temuco, IX Región de Chile. Ciencia e Investigación Agraria 31:91100.

Schnettler, B., D. Ruiz, O. Sepúlveda, and N. Sepúlveda. 2008. Importance of the country of origin in food consumption in a developing country. Food Quality and Preference 19:372-382.

Schnettler, B., R. Vidal, R. Silva, L. Vallejos, and N. Sepulveda. 2009. Consumer willingness to pay for beef meat in a developing country: The effect of information regarding country of origin, price and animal handling prior to slaughter. Food Quality and Preference 20:156-165.

Vargas-Bello-Pérez, E., R. Vera, C. Aguilar, R. Lira, I. Peña, A. Valenzuela, and H., Cerda. 2013a. Effect of dietary inclusion of lampante olive oil on milk and cheese fatty acid profiles of ewes. Grasas y Aceites 64:295-303.

Vargas-Bello-Pérez, E., R. R. Vera, C. Aguilar, R. Lira, and J. Fernández. 2013b. Feeding olive cake to ewes improves fatty acid profile of milk and cheese. Animal Feed Science and Technology 184:94-99.

Vera, R.R., C. Aguilar, and R. Lira. 2009. Differentiation of sheep milk and cheese based on quality and composition. Ciencia e Investigación Agraria 36:307-327.

Verbeke, W., and I. Vackier. 2004. Profile and effects of consumer involvement in fresh meat. Meat Science 67:159-168.

Young, N., Drake, M., Lopetcharat, K., McDaniel M., 2004. Preference mapping of Cheddar cheese with varying maturity levels. Journal of Dairy Science 87:11-19. 
